\title{
Influence of hydrological conditions on the Escherichia coli population structure in the water of a creek on a rural watershed
}

\author{
Mehdy Ratajczak ${ }^{1 *}$, Emilie Laroche ${ }^{1}$, Thierry Berthe ${ }^{1}$, Olivier Clermont², Barbara Pawlak', Erick Denamur², \\ Fabienne Petit ${ }^{1}$
}

\begin{abstract}
Background: Escherichia coli is a commensal bacterium of the gastro-intestinal tract of human and vertebrate animals, although the aquatic environment could be a secondary habitat. The aim of this study was to investigate the effect of hydrological conditions on the structure of the E. coli population in the water of a creek on a small rural watershed in France composed of pasture and with human occupation.

Results: It became apparent, after studying the distribution in the four main E. coli phylo-groups (A, B1, B2, D), the presence of the hly (hemolysin) gene and the antibiotic resistance pattern, that the E. coli population structure was modified not only by the hydrological conditions (dry versus wet periods, rainfall events), but also by how the watershed was used (presence or absence of cattle). Isolates of the B1 phylo-group devoid of hly and sensitive to antibiotics were particularly abundant during the dry period. During the wet period and the rainfall events, contamination from human sources was predominantly characterized by strains of the A phylo-group, whereas contamination by cattle mainly involved B1 phylo-group strains resistant to antibiotics and exhibiting hly. As E. coli B1 was the main phylo-group isolated in water, the diversity of 112 E. coli B1 isolates was further investigated by studying uidA alleles (beta-D-glucuronidase), the presence of hly, the O-type, and antibiotic resistance. Among the forty epidemiolgical types (ETs) identified, five E. coli B1 ETs were more abundant in slightly contaminated water.

Conclusions: The structure of an E. coli population in water is not stable, but depends on the hydrological conditions and on current use of the land on the watershed. In our study it was the ratio of A to B1 phylo-groups that changed. However, a set of B1 phylo-group isolates seems to be persistent in water, strengthening the hypothesis that they may correspond to specifically adapted strains.
\end{abstract}

\section{Background}

Ensuring the high microbiological quality of environmental water used as a source of recreational or drinking water is an important worldwide problem [1]. Poor microbiological quality of water results from contamination by microorganisms of human or animal fecal origin, and leads to the risk of gastro-enteritis in humans. Such contamination is caused by fecal bacteria from (i) point source pollution, e.g., treated effluents from wastewater treatments plants (WWTPs) which primarily treat wastewater of human origin, or (ii) nonpoint source

\footnotetext{
* Correspondence: mehdy.ratajczak@etu.univ-rouen.fr

'Laboratoire M2C, Université de Rouen, CNRS UMR 6143, FED SCALE 4116,

76821 Mont Saint Aignan, France

Full list of author information is available at the end of the article
}

pollution consisting of inputs of microorganisms of mainly animal origin, via run-off or leaching from pasture or manured soils [2-4]. The World Health Organization and, more recently, European guidelines (2006/7/ EC), use Escherichia coli as the bacterial indicator species for fecal contamination of water. Epidemiological studies have been used to determine threshold values for concentrations of $E$. coli in water above which there is a risk of gastro-enteritis [5-7].

E. coli is a commensal bacterium of the gastro-intestinal tract of humans and vertebrate animals $[8,9]$. To survive in an aqueous environment it must resist environmental stressors (oligotrophy, UV, temperature, salinity) [10-12] and avoid predation by protozoa [13]. Some authors have suggested that some of these E. coli

\section{Ciomed Central}


strains might then persist by becoming naturalized in fresh water and soil [14-16]. The aquatic environment can thus be considered a secondary habitat, where some authors have even shown the possible growth of E. coli $[17,18]$. The diversity of $E$. coli populations in their secondary habitats has been studied by analyzing the sequences of the gene uidA $[19,20]$, palindromic repetitive sequences [21,22], ribotypes [23], and profiles of antibiotic resistance [24,25]. Using these methods, the dynamics of $E$. coli populations have been investigated and, in some cases, it has been possible to discriminate between the human or animal origin of the contamination.

The structure of an E. coli population is characterized by four main phylo-groups (A, B1, B2, and D) [26-28]. Strains of the phylo-groups A and B1 are mainly found as commensals in humans and vertebrate animals, with the A phylo-group strains being predominant in humans and the B1 strains in animals [29]. Extraintestinal infections are mainly caused by the strains of the phylogroups B2 and D [30]. Although strains of the B2 and D phylo-groups are typically less abundant as commensals, the distribution of the four phylo-groups can vary according to diet or climate [9,31-33]. It also has been suggested that some strains could be host-specific, such as B1 strains exhibiting the hly (hemolysin) gene, found only in animals, and B2 O81 O-type strains, found only in humans $[34,35]$.

The objective of this study was to investigate the effects of various hydrological conditions on the structure of the E. coli population collected from stream water in a small rural watershed in northern France (Figure 1). Land use in the watershed is almost entirely agricultural with a low population density. Results show that an increase of fecal contamination was accompanied by a change in the distribution of phylo-groups in the $E$. coli population, represented by a change in the ratio of A to B1 phylo-groups. E. coli B1 isolates were the dominant phylo-group isolated in the water. Among E. coli $\mathrm{B} 1$ isolates, some epidemiological types (ETs) seem to be specific to water that is only slightly contaminated.

\section{Results and discussion}

E. coli population structure in creek water in relation to hydrological conditions and watershed land use

$E$. coli were enumerated and the population structure analyzed by phylo-grouping in three sets of samples collected under different hydrological and agricultural land-use conditions (Table 1). In this study, the E. coli population structure in creek water is analyzed from a single sample integrating all the daily samples. The origin (animal or human) of specific strains was investigated, in addition to the phylo-grouping, by hly gene detection in the E. coli $\mathrm{B} 1$ isolates and O81 typing of E. coli $\mathrm{B} 2$ isolates, as well as by studying the antibiotic resistance pattern. Statistical analyses $\left(\mathrm{Chi}^{2}\right.$ test) were performed in order to compare hydrological conditions (dry versus wet periods, rainfall events).

During the dry period (May 2007), when cattle were being grazed, but when there was no runoff or leaching, the water was slightly contaminated by E. coli $\left(6.210^{2}\right.$ CFU/100 ml) (Table 1). The structure of the E. coli population was significantly different from the structures analyzed from the other sample collection periods $\left(\chi^{2}\right.$ test $\mathrm{P}<0.001)$, with a majority of $E$. coli $\mathrm{B} 1$ isolates (87\%) (Table 2). This structure argues for contamination by $E$. coli $\mathrm{B} 1$ isolates that are better adapted to the aquatic environment [15], rather than for residual bovine fecal contamination, as the isolates were devoid of the hly gene and sensitive to all antibiotics [35,36].

It was during the wet period (February 2007), when there was no grazing, but when there was a malfunctioning septic system (4 equivalent inhabitants), that the lowest value of E. coli $\left(1.010^{2} \mathrm{CFU} / 100 \mathrm{ml}\right)$ was measured in the water. The E. coli population was characterized by a high proportion of phylo-group A isolates (47\%) $\left(\chi^{2}\right.$ test $\left.\mathrm{P}<0.001\right)$, followed by $E$. coli $\mathrm{B} 1$ isolates without the hly gene (Table 2). None of the E. coli was resistant to the seven antibiotics tested (Table 2). This E. coli population is probably due to an input of solely human origin, as the structure corresponds to that already described for human commensal $E$. coli in France [31,32].

The rainfall event that occurred during the dry period (July 2007) resulted in runoff from the pastures and leaching of soils. The density of the $E$. coli in the stream water $\left(4.010^{4} \mathrm{CFU} / 100 \mathrm{ml}\right)$ was two orders of magnitude higher than that measured for the two other periods (Table 1). During this rain event, an input of E. coli from cattle contamination (172 head of cattle) was added to that from human contamination (147 eq. inhabitants, 49 septic tanks, and the malfunctioning septic tank). The structure of the E. coli population was characterized by two main phylo-groups, B1 (44\%) and A (32\%). Some E. coli B1 isolates with the hly gene, presumably of animal origin were detected (2/15) [35]. More than $60 \%$ of these isolates were resistant to at least one of the three antibiotics used in veterinary medicine (chloramphenicol, tetracycline, and streptomycin) [37] (Table 2), suggesting an animal origin.

Thus, it appears that both hydrological conditions and current land use in the watershed might affect the structure of the E. coli A and B1 populations in the stream. In contrast, the hydrological and land-use conditions did not exert a significant influence on the phylo-groups B2 and $\mathrm{D}$, which were the least abundant phylo-groups recovered from the water (between 0 and 23\%). No human-specific 


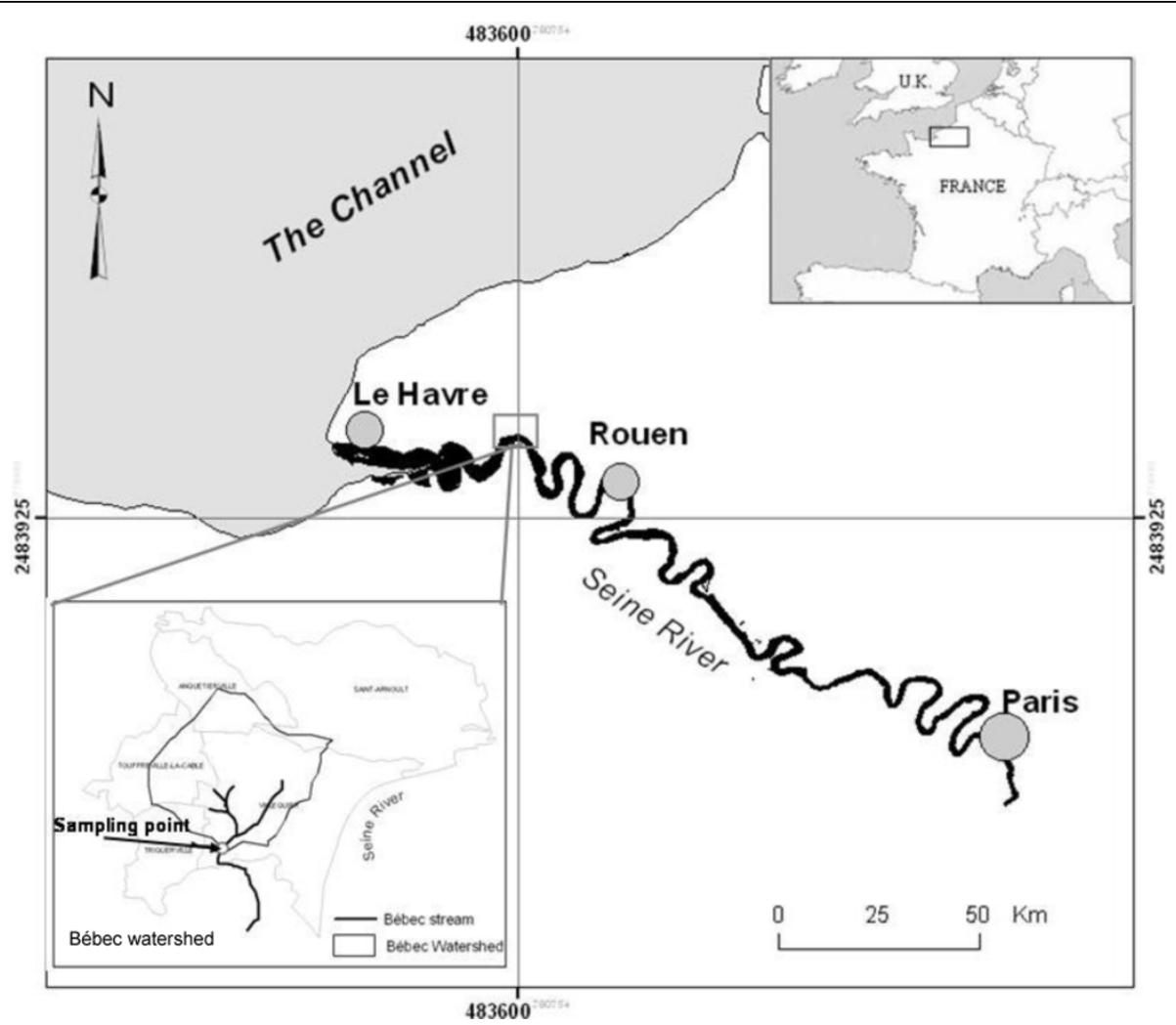

Figure 1 Location of study site and sample collection point.

B2 O81 O-type strain was isolated during any sampling conditions, which is consistent with the low frequency of these strains in the E. coli population [34].

\section{Changes in E. coli population structure during a rain} event

In order to better understand the effect of a rain event on the structure of an E. coli population, we selected three out of the twenty-four hourly samples. Our selection represented three key moments ( 5 hours before, 6 hours after, and 19 hours after the rain event) showing how the turbidity and $E$. coli density evolved. It would not have been possible to observe this evolution using just a sample that integrated all the daily samples. The rain event consisted of $14 \mathrm{~mm}$ of rain that fell during a wet period, during which there were 42 cattle being

Table $1 \mathrm{E}$. coli enumeration in creek water according to land use in the watershed, and hydrological parameters

\begin{tabular}{|c|c|c|c|c|c|c|c|}
\hline & \multirow{3}{*}{$\begin{array}{c}\text { Sampling } \\
\text { date } \\
\text { (day/mo/yr) }\end{array}$} & \multicolumn{4}{|c|}{ Hydrological conditions } & \multirow{3}{*}{$\begin{array}{c}\begin{array}{c}\text { Use of the } \\
\text { watershed }^{\mathrm{a}}\end{array} \\
\begin{array}{c}\text { Head of } \\
\text { cattle }\end{array}\end{array}$} & \multirow{3}{*}{$\begin{array}{c}\text { E. coli } \\
\begin{array}{c}\text { CFU/100 } \\
\mathrm{ml}\end{array}\end{array}$} \\
\hline & & \multicolumn{2}{|c|}{ Rainfall (mm) } & \multirow{2}{*}{$\begin{array}{c}\text { Turbidity } \\
\left.\left(N_{T}\right)^{b}\right)\end{array}$} & \multirow[t]{2}{*}{$\mathrm{SSC}^{\mathrm{C}}\left(\mathrm{mg} \mathrm{L}^{-1}\right)$} & & \\
\hline & & $\begin{array}{l}\text { Within } 5 \text { days } \\
\text { of sampling }\end{array}$ & $\begin{array}{l}\text { On day of } \\
\text { sampling }\end{array}$ & & & & \\
\hline Wet period & 21 Feb 2007 & 27.8 & 2.0 & 15.0 & 23.0 & 0 & $\begin{array}{c}(1.0 \pm 0.1) \\
10^{2}\end{array}$ \\
\hline Dry period & 3 May 2007 & 3.8 & 0.0 & 3.1 & 11.4 & 172 & $\frac{(6.2 \pm 0.6)}{10^{2}}$ \\
\hline $\begin{array}{l}\text { Rainfall event during dry } \\
\text { period }\end{array}$ & 11 July 2007 & 8.9 & 50.0 & 33.0 & 74.4 & 172 & $\begin{array}{c}(4.0 \pm 0.7) \\
10^{4}\end{array}$ \\
\hline
\end{tabular}


Table 2 Structure and antibiotic resistance of the $E$. coli population in the stream during different hydrological conditions $\left(\chi^{2}\right.$ test $\left.P<0.001 * * * \alpha=0.01\right)$

\begin{tabular}{|c|c|c|c|c|c|c|c|c|c|c|c|c|c|c|}
\hline \multirow[b]{3}{*}{$\begin{array}{l}\text { Hydrologic } \\
\text { conditions }\end{array}$} & \multicolumn{14}{|c|}{ E. coli phylo-group distribution } \\
\hline & \multicolumn{3}{|c|}{ A } & \multicolumn{4}{|c|}{ B1 } & \multicolumn{4}{|c|}{ B2 } & \multicolumn{3}{|c|}{ D } \\
\hline & $\begin{array}{l}\% \\
\text { (n) }\end{array}$ & $\begin{array}{l}\text { Numbers } \\
\text { of } \\
\text { antibiotic- } \\
\text { resistant }^{\mathrm{a}}\end{array}$ & $\begin{array}{l}\text { Antibiotic } \\
\text { resistance }^{\text {b }} \\
\text { (n) }\end{array}$ & $\begin{array}{l}\% \\
\text { (n) }\end{array}$ & $h / y^{c}$ & $\begin{array}{l}\text { Numbers } \\
\text { of } \\
\text { antibiotic- } \\
\text { resistant }^{\text {a }}\end{array}$ & $\begin{array}{l}\text { Antibiotic } \\
\text { resistance } \\
\text { (n) }\end{array}$ & $\begin{array}{l}\% \\
\text { (n) }\end{array}$ & $081^{d}$ & $\begin{array}{l}\text { Numbers } \\
\text { of } \\
\text { antibiotic- } \\
\text { resistant }^{\mathrm{a}}\end{array}$ & $\begin{array}{l}\text { Antibiotic } \\
\text { resistance }^{b} \\
\text { (n) }\end{array}$ & $\begin{array}{l}\% \\
\text { (n) }\end{array}$ & $\begin{array}{c}\text { Numbers } \\
\text { of } \\
\text { antibiotic- } \\
\text { resistant }^{\text {a }}\end{array}$ & $\begin{array}{l}\text { Antibiotic } \\
\text { resistance }^{\text {b }} \\
\text { (n) }\end{array}$ \\
\hline Wet period & $\begin{array}{l}47 \% \\
(21) \\
* * *\end{array}$ & 0 & nd & $\begin{array}{l}39 \% \\
(17) \\
* * *\end{array}$ & 0 & 0 & nd & $\begin{array}{l}7 \% \\
(3)\end{array}$ & 0 & 0 & nd & $\begin{array}{l}7 \% \\
(3)\end{array}$ & 0 & nd \\
\hline Dry period & $\begin{array}{l}7 \% \\
(3) \\
* * *\end{array}$ & 0 & nd & $\begin{array}{l}87 \% \\
(39) \\
* * *\end{array}$ & 0 & 0 & nd & $\begin{array}{l}2 \% \\
(1)\end{array}$ & 0 & 0 & nd & $\begin{array}{l}4 \% \\
(2)\end{array}$ & 0 & nd \\
\hline $\begin{array}{l}\text { Rain event } \\
\text { during dry } \\
\text { period }\end{array}$ & $\begin{array}{l}32 \% \\
(11)\end{array}$ & 7 & $\begin{array}{l}\text { CHL(3) TET } \\
\text { (3) STR(1) }\end{array}$ & $\begin{array}{l}44 \% \\
(15)\end{array}$ & 2 & 10 & $\begin{array}{c}\mathrm{CHL} \text { (5) TET } \\
\text { (3) CHL/TET } \\
\text { (2) }\end{array}$ & $\begin{array}{l}0 \% \\
(0)\end{array}$ & nd & nd & nd & $\begin{array}{c}23 \% \\
(8)\end{array}$ & 2 & $\begin{array}{c}\mathrm{CHL} / \mathrm{TET}(1) \\
\mathrm{CHL}(1)\end{array}$ \\
\hline
\end{tabular}

$\mathrm{n}$ : numbers of isolates

${ }^{a}$ E. coli isolates resistant to one or more antibiotics

${ }^{b}$ CHL: chloramphenicol; TET: tetracyclin; STR: streptomycin

nd: not detected

c hly gene detection by PCR method

d Serotype 081 detection by PCR method

grazed in the watershed (March 2008) (Figure 2). Five hours before rainfall began, the level of $E$. coli contamination was low $\left(7.610^{1} \mathrm{CFU} / 100 \mathrm{ml}\right)$, and the small number of isolates did not permit analysis of the structure of the E. coli population (Table 3). During the rain event, the turbidity increased, as did the number of $E$. coli, consistent with previous work demonstrating a correlation between bacteria and particles [38]. Six hours after the rainfall event the $E$. coli density reached a value of $7.210^{2} \mathrm{CFU} / 100 \mathrm{ml}$, at which point the structure of the $E$. coli population was characterized by a majority of $E$. coli phylo-group A (56\%), with $63 \%$ being resistant to at least one antibiotic (amoxicillin, chloramphenicol, tetracycline, and streptomycin), suggesting fecal contamination of human origin resulting from leaching of soils and from surface runoff (Table 3). This structure was significantly different from that observed in the less contaminated water analyzed 19 hours after the rainfall event $\left(\chi^{2}\right.$ test $\mathrm{P}<$ $0.001)$. At that time the E. coli density had decreased to $2.810^{2} \mathrm{CFU} / 100 \mathrm{ml}$ (Figure 2), and E. coli $\mathrm{B} 1$ isolates $(74 \%)$ were the predominant $E$. coli phylo-group. These isolates are mainly hly positive (72\%) with $31 \%$ resistant to at least one antibiotic (amoxicillin, tetracycline, and chloramphenicol), suggesting that there had been an input on the soils of $E$. coli of bovine origin that was then introduced into the water through runoff and/or leaching.

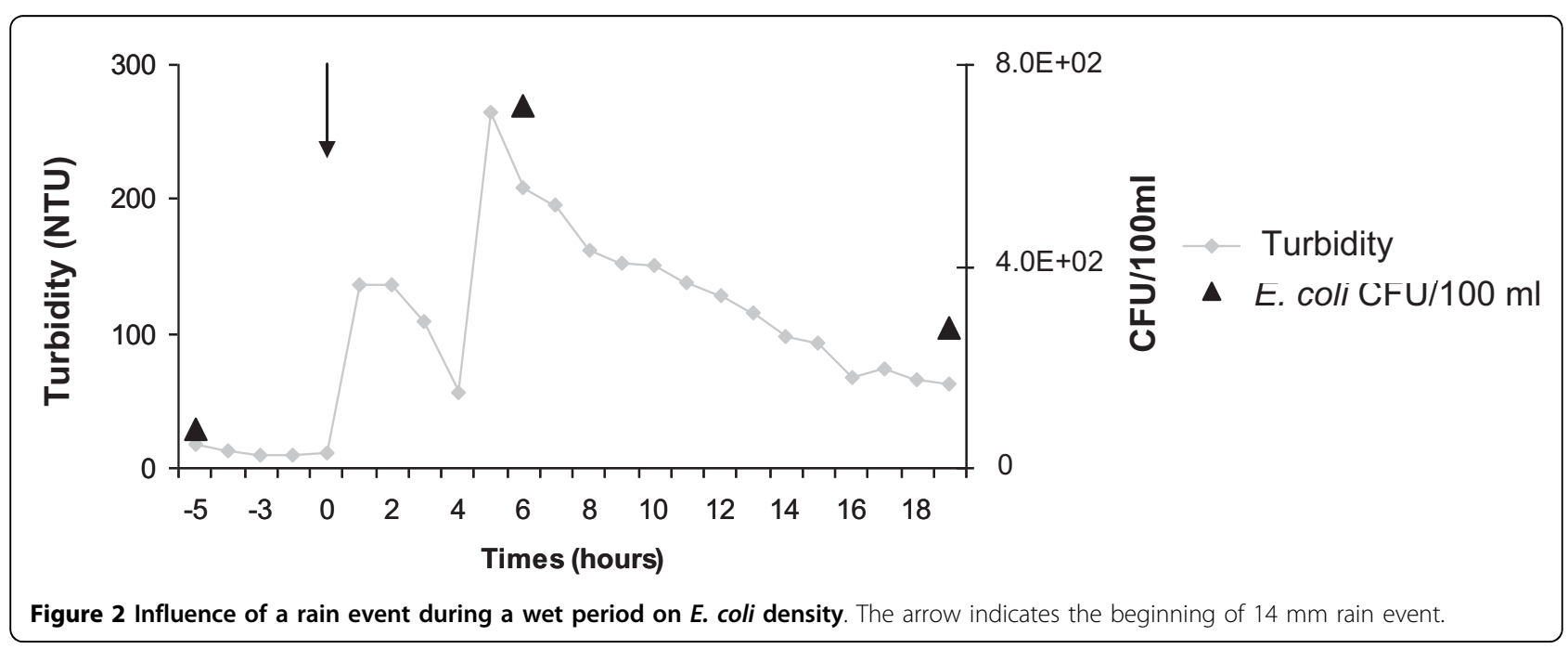


Table 3 Structure and antibiotic resistance of the $E$. coli population in the stream in response to a rain event $\left(\chi^{2}\right.$ test $P<0.001 * * * \alpha=0.01$ )

\begin{tabular}{|c|c|c|c|c|c|c|c|c|c|c|c|c|c|c|}
\hline \multirow[b]{3}{*}{$\begin{array}{l}\text { Timing } \\
(\mathrm{h})^{\mathrm{a}}\end{array}$} & \multicolumn{14}{|c|}{ E. coli p-group distribution } \\
\hline & \multicolumn{3}{|c|}{ A } & \multicolumn{4}{|c|}{ B1 } & \multicolumn{4}{|c|}{ B2 } & \multicolumn{3}{|c|}{$\mathrm{D}$} \\
\hline & $\begin{array}{l}\% \\
\text { (n) }\end{array}$ & $\begin{array}{c}\text { Numbers } \\
\text { of } \\
\text { antibiotic- } \\
\text { resistant }^{\mathrm{b}}\end{array}$ & $\begin{array}{c}\text { Antibiotic } \\
\text { Resistance }^{c} \\
\text { (n) }\end{array}$ & $\begin{array}{l}\% \\
(n)\end{array}$ & $h l y^{d}$ & $\begin{array}{c}\text { Numbers } \\
\text { of } \\
\text { antibiotic- } \\
\text { resistant }^{\mathbf{b}}\end{array}$ & $\begin{array}{c}\text { Antibiotic } \\
\text { Resistance }^{c} \\
\text { (n) }\end{array}$ & $\begin{array}{l}\% \\
\text { (n) }\end{array}$ & $081^{e}$ & $\begin{array}{c}\text { Numbers } \\
\text { of } \\
\text { antibiotic- } \\
\text { resistant }^{\mathbf{b}}\end{array}$ & $\begin{array}{l}\text { Antibiotic } \\
\text { resistance }^{c} \\
\text { (n) }\end{array}$ & $\begin{array}{l}\% \\
\text { (n) }\end{array}$ & $\begin{array}{c}\text { Numbers } \\
\text { of } \\
\text { antibiotic- } \\
\text { resistant }^{\mathbf{b}}\end{array}$ & $\begin{array}{l}\text { Antibiotic } \\
\text { resistance } \\
\text { (n) }\end{array}$ \\
\hline$-5 \mathrm{~h}$ & $\begin{array}{c}25 \% \\
(3)\end{array}$ & 2 & $\begin{array}{l}\mathrm{AMX} / \mathrm{CHL} \\
\text { (1) } \mathrm{CHL}(1) \text {. }\end{array}$ & $\begin{array}{c}50 \% \\
(6) \\
\end{array}$ & 0 & 4 & $\mathrm{CHL}(4)$ & $\begin{array}{l}8 \% \\
(1) \\
\end{array}$ & 0 & 0 & nd & $\begin{array}{c}17 \% \\
(2) \\
\end{array}$ & 0 & nd \\
\hline$+6 \mathrm{~h}$ & $\begin{array}{l}56 \% \\
(22) \\
* * *\end{array}$ & 14 & $\begin{array}{c}\text { AMX/TIC/ } \\
\text { CHL(5) } \\
\text { AMX/TIC/ } \\
\text { CHL/SXT/ } \\
\text { STR(1) } \\
\text { AMX/TIC/ } \\
\text { SXT/STR(1) } \\
\text { CHL(6) } \\
\text { CHL/TET(1) }\end{array}$ & $\begin{array}{l}15 \% \\
(6) \\
* * *\end{array}$ & 1 & 3 & $\mathrm{CHL}(3)$ & $\begin{array}{l}8 \% \\
(3)\end{array}$ & 0 & 2 & $\mathrm{CHL}(2)$. & $\begin{array}{c}21 \% \\
(8)\end{array}$ & 4 & $\begin{array}{c}\text { AMX/TIC/ } \\
\text { SXT/STR(1) } \\
\text { CHL(3) }\end{array}$ \\
\hline$+19 \mathrm{~h}$ & $\begin{array}{c}15 \% \\
(6) \\
* * *\end{array}$ & 3 & $\begin{array}{c}\mathrm{AMX/CHL} \\
(1) \\
\text { AMX/TIC/ } \\
\text { CHL(1) } \\
\text { AMX/TIC(1) }\end{array}$ & $\begin{array}{l}74 \% \\
(29) \\
* * *\end{array}$ & 21 & 9 & $\begin{array}{c}\mathrm{TET}(1) \mathrm{CHL} \\
\text { (7) AMX/ } \\
\text { CHL/TET(1) }\end{array}$ & $\begin{array}{l}5 \% \\
(2)\end{array}$ & 0 & 2 & $\mathrm{CHL}(2)$. & $\begin{array}{l}5 \% \\
(2)\end{array}$ & 1 & $\mathrm{CHL}(1)$ \\
\hline
\end{tabular}

nd: not detected

$\mathrm{n}$ : numbers of isolates

a Timing in relation to rainfall

${ }^{\mathrm{b}} \mathrm{E}$. coli isolates resistant to one or more antibiotics

c AMX: amoxicillin; TIC: ticarcillin CHL: chloramphenicol; TET: tetracyclin; STR: streptomycin; SXT:trimethoprim + sulfamethoxazole

d hly gene detection by PCR method

e Serotype 081 detection by PCR method

We cannot exclude an input from wild animals (mainly birds and rabbits), although wild E. coli strains are usually not resistant to antibiotics [39]. These results indicate that during the rain event, an increase in microbial contamination was accompanied by a modification of the structure of the E. coli population, resulting in a high ratio of phylo-groups A/B1. In contrast, in the water collected $19 \mathrm{~h}$ after the rain event, and only slightly contaminated by $E$. coli, the majority of $E$. coli isolates belonged to the B1 phylo-group.

\section{Diversity of E. coli B1 strains isolated from the creek water}

As $E$. coli $\mathrm{B} 1$ was the dominant phylo-group isolated in water from the Bébec, accounting for between 15\% to $87 \%$ of the E. coli population (Tables 2 and 3), we investigated further the diversity of $E$. coli B1 isolates by (i) sequencing the uidA gene (beta-D-glucuronidase, $600 \mathrm{pb}$ ) and comparing the sequences obtained with those in the MLST Pasteur database in order to find the uidA allele, (ii) detecting the presence of $h l y$ and determining molecularly the O-type, (iii) studying the antibiotic resistance profile.

A total of 40 epidemiological types (ETs) were identified among the $112 \mathrm{E}$. coli $\mathrm{B} 1$ isolated from the water (Table 4) and the proportion of each ETs differed for each sampling event (Figure 3A and 3B).
In the most contaminated water $\left(4.0 \pm 0.710^{4} \mathrm{CFU} /\right.$ $100 \mathrm{ml}$ ), the diversity of $E$. coli B1 strains (i.e., number of ETs/total number of B1 isolates for the sampling campaign) was higher $(12 / 15)$ than in less contaminated water $\left(9 / 17\right.$ in water containing $1.0 \pm 0.110^{2} \mathrm{CFU} / 100$ $\mathrm{ml} ; 12 / 39$ in water containing $6.2 \pm 0.610^{2} \mathrm{CFU} / 100$ $\mathrm{ml}$ ) (Figure 3A). At the peak of the turbidity, E. coli density reached a value of $7.210^{2} \mathrm{CFU} / 100 \mathrm{ml}$, the diversity of $E$. coli B1 strains was higher (6/6) than the diversity observed when turbidity and E. coli density decreased (10/29) (Figure 3B).

Among the 40 ETs, strains of the group ET1.1 were present in all samples, regardless of the hydrological condition or the current land use in the watershed. However, they made up a greater proportion of the strains under non-storm conditions: during the dry period (no contribution of fecal bacteria from the watershed), 13 ET1.1/39 E. coli B1 were present, and during the wet period (a low contribution of humanderived fecal material, but none from livestock) 6 ET1.1/ 17 E. coli $\mathrm{B} 1$ were present (Figure 3A). In contrast, other ETs were present only under certain hydrological conditions and/or land-use conditions. ET1.7 and ET14.1 were present only during the dry period. ET3.4 was present after the rain event only when the turbidity decreased after the peak had been reached (Figure 3B). 
Table 4 Epidemiological types of E. coli B1 strains recovered from creek water

\begin{tabular}{|c|c|c|c|c|c|c|c|}
\hline \multirow[t]{2}{*}{ Epidemiological types } & \multirow[t]{2}{*}{ uidA allele } & \multirow[t]{2}{*}{ hly } & \multicolumn{3}{|c|}{ Antibiotic $^{\mathrm{a}}$} & \multirow[t]{2}{*}{ O-type } & \multirow[t]{2}{*}{ Numbers of isolates } \\
\hline & & & AMX & $\mathrm{CHL}$ & TET & & \\
\hline ET 1.1 & uidA2 & 0 & 0 & 0 & 0 & NT & 27 \\
\hline ET 1.2 & uidA2 & 1 & 0 & 0 & 0 & NT & 1 \\
\hline ET 1.3 & uidA2 & 0 & 0 & 1 & 0 & NT & 4 \\
\hline ET 1.4 & uidA2 & 0 & 0 & 0 & 1 & NT & 2 \\
\hline ET 1.5 & uidA2 & 0 & 0 & 1 & 1 & NT & 1 \\
\hline ET 1.6 & uidA2 & 0 & 0 & 0 & 0 & 08 & 1 \\
\hline ET 1.7 & uidA2 & 0 & 0 & 0 & 0 & 015 & 5 \\
\hline ET 1.8 & uidA2 & 0 & 0 & 0 & 0 & 026 & 1 \\
\hline ET 1.9 & uidA2 & 0 & 0 & 0 & 0 & 040 & 3 \\
\hline ET 2 & uidA4 & 0 & 0 & 0 & 0 & NT & 1 \\
\hline ET 3.1 & UidA5 & 0 & 0 & 0 & 0 & NT & 3 \\
\hline ET 3.2 & uidA5 & 1 & 0 & 0 & 0 & NT & 4 \\
\hline ET 3.3 & uidA5 & 1 & 0 & 1 & 0 & NT & 1 \\
\hline ET 3.4 & uidA5 & 1 & 0 & 0 & 0 & 07 & 13 \\
\hline ET 3.5 & uidA5 & 1 & 0 & 1 & 0 & 07 & 2 \\
\hline ET 3.6 & uidA5 & 0 & 0 & 1 & 0 & 07 & 1 \\
\hline ET 3.7 & uidA5 & 1 & 0 & 0 & 0 & 088 & 1 \\
\hline ET 4 & uidA11 & 0 & 0 & 1 & 0 & NT & 1 \\
\hline ET 5 & uidA20 & 0 & 0 & 0 & 0 & NT & 1 \\
\hline ET 6 & uidA21 & 0 & 0 & 1 & 0 & NT & 1 \\
\hline ET 7 & uidA22 & 0 & 0 & 0 & 0 & 015 & 1 \\
\hline ET 8.1 & uidA30 & 0 & 0 & 0 & 0 & 07 & 1 \\
\hline ET 8.2 & uidA30 & 0 & 0 & 1 & 0 & 07 & 1 \\
\hline ET 8.3 & uidA30 & 1 & 0 & 0 & 0 & NT & 1 \\
\hline ET 9.1 & uidA50 & 0 & 0 & 1 & 0 & NT & 2 \\
\hline ET 9.2 & uidA50 & 0 & 0 & 0 & 0 & 015 & 1 \\
\hline ET 10.1 & uidA55 & 0 & 0 & 0 & 0 & NT & 2 \\
\hline ET 10.2 & uidA55 & 0 & 0 & 1 & 0 & NT & 1 \\
\hline ET 11 & uidA57 & 0 & 0 & 0 & 0 & 08 & 1 \\
\hline ET 12 & uidA65 & 0 & 0 & 1 & 0 & NT & 4 \\
\hline ET 13 & uidA66 & 0 & 0 & 1 & 0 & 026 & 1 \\
\hline ET 14.1 & uidA90 & 0 & 0 & 0 & 0 & 0150 & 8 \\
\hline ET 14.2 & uidA90 & 0 & 0 & 0 & 0 & 015 & 3 \\
\hline ET 14.3 & uidA90 & 0 & 0 & 0 & 1 & 026 & 1 \\
\hline ET 15 & uidA103 & 0 & 0 & 0 & 0 & NT & 1 \\
\hline ET 16 & uidA110 & 0 & 0 & 0 & 0 & NT & 3 \\
\hline ET 17.1 & uidA111 & 0 & 0 & 0 & 0 & NT & 3 \\
\hline ET 17.2 & uidA111 & 0 & 0 & 1 & 1 & NT & 1 \\
\hline ET 17.3 & uidA111 & 0 & 1 & 1 & 1 & NT & 1 \\
\hline ET 18 & New allele & 1 & 0 & 0 & 1 & 07 & 1 \\
\hline
\end{tabular}

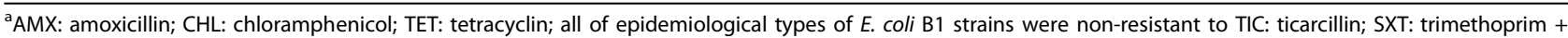
sulfamethoxazole; STR: streptomycin; and CIP: ciprofloxacin.

${ }^{\mathrm{b}} \mathrm{NT}$ : not 07, 08, 015, 026, O40, 045b, 078, 081, 088, 0103, 0104, 0111, 0128, or 0150.

The binary coding stands for presence (1) or absence (0) of hly gene amplification, and resistance (1) or non-resistance (0) to antibiotics.

These results indicate that specific E. coli B1 ETs are more abundant in water that is only slightly contaminated, suggesting better survival of these ETs. These results strengthen the hypothesis of Walk et al., [15], that some strains of $E$. coli B1 phylo-group are persistent in water and might correspond to strains with an adaptive advantage in water. However, it must be pointed out that in this work, the E. coli $\mathrm{A}_{0}$ isolates (50/ 213), without any amplification of the genes $\operatorname{chuA}$, yjaA and the fragment TSPE4.C2, could correspond to the new clades of Escherichia recently described which appear to be environmentally adapted [40]. 


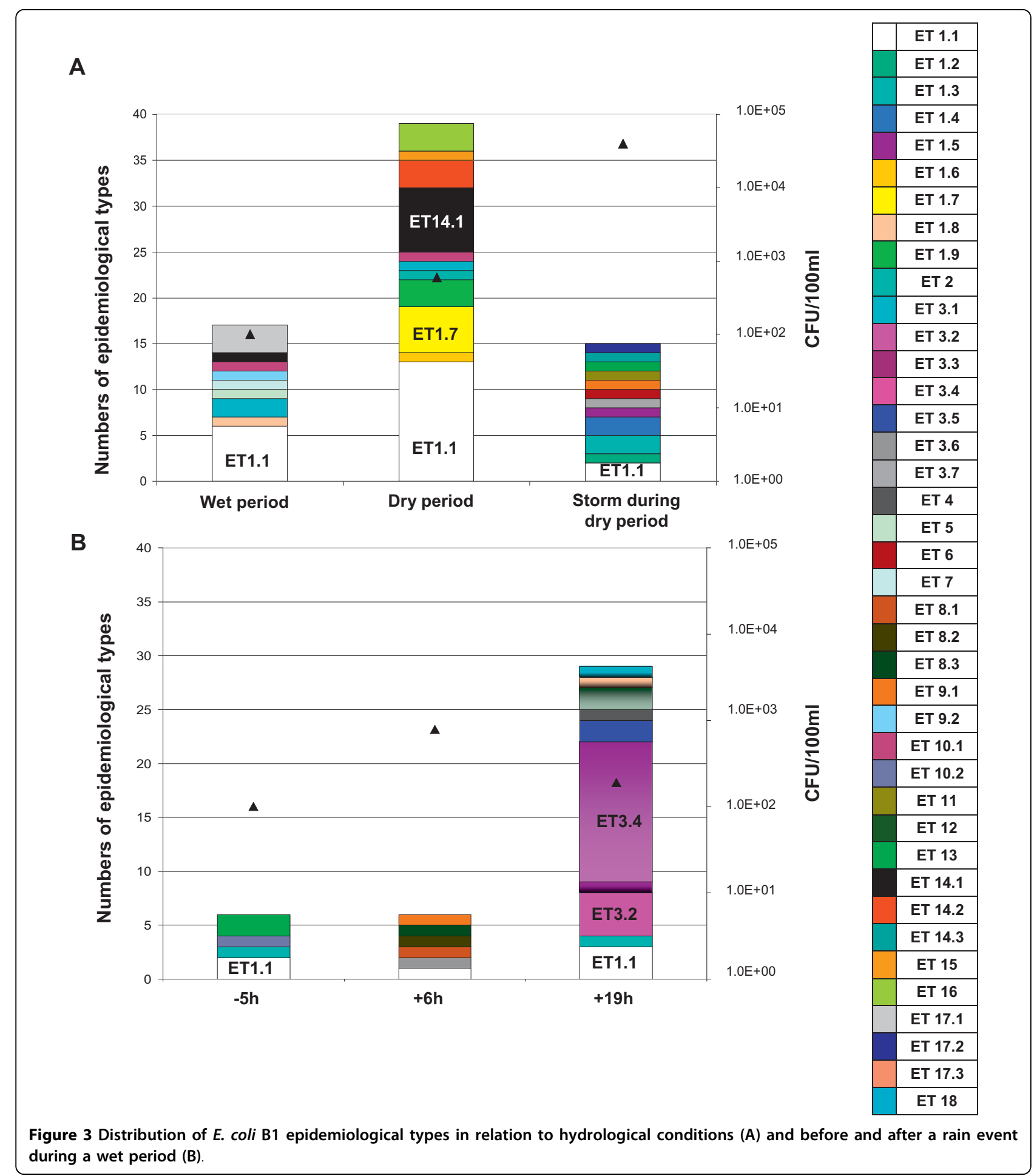

\section{Conclusions}

In environmental water, the occurrence of E. coli, a bacterial indicator of fecal contamination, is related to both the use of the watershed by livestock and humans combined and the hydrological conditions [2,3,41]. In this study, focused on a small rural watershed composed of pasture and human occupation, we showed that both the number and the structure of the population of E. coli were modified by hydrological conditions and use of the watershed. In this watershed, following rainfall, an increase of fecal contamination was accompanied by a modification of the distribution of phylo-groups in the 
E. coli population, represented by change in the ratio of A to B1 phylo-groups. E. coli B1 strains were the dominant phylo-group isolated in the water. Among E. coli B1 isolates, some ETs seem to be specific to water that is only slightly contaminated, suggesting different survival abilities among E. coli B1 strains.

The results from this study do not question the choice of $E$. coli as a bacterial indicator of microbial quality of water DCE 2006/7/CE (Excellent quality CFU/100 ml $\leq 500$ ). They rather indicate that the structure of an $E$. coli population in water is not stable, but depends on the hydrological conditions, on current use of the watershed land, and on both the origin and intensity of the contamination by fecal bacteria.

\section{Methods}

Study site

The study was carried out in the experimental watershed "Le Bébec" (Haute Normandie, France) (Figure 1). The Bébec stream drains a small watershed of about $10 \mathrm{~km}^{2}$, of which $95 \%$ is classified as agricultural land. The elevation of the plateau on which Le Bébec is located averages about $100 \mathrm{~m}$. The soils on the plateau consist of silts approximately $10 \mathrm{~m}$ thick, and are highly susceptible to crusting, compaction, and erosion, particularly during the autumn and winter. This watershed is located in a temperate zone with an oceanic climate. Annual precipitation during the period of the study was $1012 \mathrm{~mm}$, and the daily average temperature was $10.9^{\circ}$ C. Flow in the Bébec varied from $31 . \mathrm{s}^{-1}$ in summer dry periods to $151 . \mathrm{s}^{-1}$ in winter, and reached up to $500 \mathrm{l} . \mathrm{s}^{-1}$ in response to major winter storms. Water from the creek recharges the underlying chalk aquifer through a swallow hole. The karstified chalk aquifer has been widely studied [38]. When the flow rate in the stream exceeds the infiltration capacity of the swallow hole, the creek water overflows its banks and floods the valley. Land use in the area consists of approximately 55\% cropland, $30 \%$ pasture (42 beef cattle, 130 dairy cattle), and $10 \%$ forest, with the remaining $5 \%$ divided among several other uses. The 213 households in the watershed (639 equivalent inhabitants) rely on on-site septic systems. Among them, 49 septic tanks (147 equivalent inhabitants) were located on a 500 to $600 \mathrm{~m}$ stretch of the stream. Untreated sewage of human origin (4 equivalent inhabitants) resulting from a dysfunctional septic system was located $400 \mathrm{~m}$ from the sampling location corresponding to a input of $E$. coli which varies from $6.510^{1}$ CFUs per $100 \mathrm{ml}^{-1}$ in a wet period to 3.6 $10^{4} \mathrm{CFUs}$ per $100 \mathrm{ml}^{-1}$ after a rainfall event. The landuse data were provided by the "Groupement d'Intéret Public Seine Aval", and data on beef and dairy cattle were provided by the "Direction Départementale de l'Agriculture et de la Forêt (DDAF)".

\section{Materials and sampling method}

Samples were collected with autosamplers (ISCO 6700 s, Roucaire, Courtaboeuf, France) from the stream, near the swallow hole, during a wet period in February 2007 (high flow) and during a dry period in May 2007 (low flow), after a storm during a dry period in July 2007 (Table 1), and after a storm during a wet period in March 2008, with samples taken $5 \mathrm{~h}$ before the storm, 6 $\mathrm{h}$ after the storm, and $19 \mathrm{~h}$ after the storm (Figure 2). The site was equipped with dataprobes (YSI 6820) to measure turbidity. Suspended sediment concentration was measured by filtration through pre-weighed Millipore filters $(0.45 \mu \mathrm{m})$. Water $(1 \mathrm{~L})$ was collected by autosamplers every hour for $24 \mathrm{~h}, 250 \mathrm{ml}$ of each flask were mixed until subsequent microbial analysis, except for the sampling campaign in March 2008. All samples were kept at $4^{\circ} \mathrm{C}$ until the microbiological analyses were carried out, which occurred within $8 \mathrm{~h}$.

\section{Enumeration of culturable $E$. coli}

E. coli were enumerated using membrane filtration methods $(0.45 \mu \mathrm{m}$ HA047 Millipore, Bedford, MA, USA). E. coli were isolated from the water samples with a selective chromogenic media specific for $E$. coli, with the addition of a selective supplement for water samples (RAPID'E.coli 2 Medium and Supplement; Biorad, USA), and incubated for $24 \mathrm{~h}$ at $44^{\circ} \mathrm{C}$. The threshold value for the enumeration of $E$. coli in water was 5 CFUs per $100 \mathrm{ml}^{-1}$.

\section{E. coli isolates}

Two hundred and thirteen isolates of E. coli were isolated from the creek water. The isolates were taken from the membrane of RAPID'E.coli 2 medium and isolated on RAPID'E.coli 2 medium for $24 \mathrm{~h}$ at $37^{\circ} \mathrm{C}$. Each clone of $E$. coli was stored on a cryo-bead system (AES laboratory, France) at $-80^{\circ} \mathrm{C}$. Four sets of isolates were obtained from the stream under different hydrological conditions: 44 isolates during dry season conditions (February 2007); 45 isolates during wet season conditions (May 2007); 34 isolates after a storm during the dry period (July 2007); and 90 isolates from the storm during the wet period (March 2008).

\section{Determination of the $E$. coli phylo-groups, $O$ type, and presence of the hly gene}

The phylogenetic group to which the $E$. coli isolates belonged was determined by the PCR-based method, as described previously by Clermont et al. [42]. A total of 112 isolates of E. coli B1 were tested for the virulence factor hly by the PCR amplification method as described by Escobar-Páramo et al. [34] (hly.1: 5'-AGG-TTCTTG-GGC-ATG-TAT-CCT-3'; hly.2: 5'-TTG-CTTTGC-AGA-CTG-CAG-GTG-T-3'). All E. coli B2 were 
tested for the O81 type [10], and all E. coli B1 strains were tested for $\mathrm{O} 7, \mathrm{O} 8, \mathrm{O} 15, \mathrm{O} 26, \mathrm{O} 40, \mathrm{O} 45 \mathrm{~b}, \mathrm{O} 78$, O81, O88, O103, O104, O111, O128 and O150 types by using the PCR-based method described by Clermont et al. [43] with the primers shown in [Additional file 1]. These $\mathrm{O}$ types have been previously shown to be present in B1 group strains (Clermont and Denamur, personal data).

\section{Antibiotic resistance testing}

Antibiotic resistance was determined by the agar diffusion method using seven antibiotic disks (BioMérieux, France): amoxicillin (AMX), ticarcillin (TIC), chloramphenicol (CHL), tetracycline (TET), trimethoprim + sulfamethoxazole (SXT), ciprofloxacin (CIP), and streptomycin (STR). Among them CHL, TET, STR are used in veterinary medicine. After $24 \mathrm{~h}$ of incubation at $37^{\circ} \mathrm{C}$, the bacteria were classified as sensitive, intermediate, or resistant according to French national guidelines [44]. The E. coli CIP 7624 (ATCC 25922) was taken as the quality control strain. The data were regrouped as resistant or non-resistant, the latter corresponding to sensitive and intermediate phenotypes.

\section{Allele number attribution of uidA gene of $E$. coli B1}

Partial uidA sequences $(600 \mathrm{pb})$ of 112 E. coli B1 isolates from the stream (17, dry season; 39, wet season; 15 , storm during dry period; 41 , storm during wet period [6, 6, and $195 \mathrm{~h}$ before the storm, $6 \mathrm{~h}$ after the storm, and $19 \mathrm{~h}$ after the storm, respectively]) were sequenced after PCR amplification (uidAR: 5'-CCATCA-GCA-CGT-TAT-CGA-ATC-CTT-3'; uidAF:5' CAT-TAC-GGC-AAA-GTG-TGG-GTC-AAT-3').

Thirty-five $\mu \mathrm{l}$ of $\mathrm{PCR}$ product, containing an estimated $100 \mathrm{ng} / \mu \mathrm{l}$ of DNA, were sequenced in both forward and reverse directions at Cogenics (Meylan, France). A consensus sequence was determined by aligning the forward sequence with the reverse complement of the reverse sequence. Alleles of uidA were determined by comparison of the uidA sequences found in the MLST database Pasteur http://www.pasteur.fr/cgi-bin/genopole/PF8/ mlstdbnet.pl?file=Eco_profiles.xml.

\section{Statistical analyses}

The frequencies of various phylo-groups in the water samples were compared using the chi-square test. Tests were carried out using the XLSTATS version 6.0 (Addinsoft).

\section{Additional material}

Additional file 1: List of primers used in the study for PCR O-typing.

\section{Abbreviations}

AMX: amoxicillin; CFUs: colony-forming units; CHL: chloramphenicol; CIP: ciprofloxacin; ET: epidemiological type; MLST: multi locus sequence typing; PCR: polymerase chain reaction; TET: tetracycline; TIC: ticarcillin; STR: streptomycin; SXT: trimethoprim + sulfamethoxazole.

\section{Acknowledgements}

MR held a research grant from the "Conseil Régional de Haute Normandie" (France). ED was partially supported by the "Fondation pour la Recherche Médicale". The authors thank Dr Barbara J. Malher (U.S. Geological Survey) for constructive remarks on the manuscript and help in editing. We would like to thank Dilys Moscato for helping with the English of this manuscript.

\section{Author details}

'Laboratoire M2C, Université de Rouen, CNRS UMR 6143, FED SCALE 4116, 76821 Mont Saint Aignan, France. ${ }^{2}$ Laboratoire Ecologie et évolution des microorganismes, Université Paris 7 Denis Diderot and INSERM U722, 75018 Paris, France.

\section{Authors' contributions}

The work presented here was carried out in collaboration with all authors. $M R$, TB and FP defined the research theme. MR, TB and FP defined sampling strategy and designed methods and experiments. EL and BP defined sampling strategies during the rain event. MR carried out the laboratory experiments, and EL carried out antibiotic resistance analysis. MR and FP analyzed the data, interpreted the results and wrote the paper. $O C$ and ED co-designed experiments, discussed analyses, interpretation and presentation. All authors have contributed to, seen and approved the final manuscript.

Received: 2 March 2010 Accepted: 19 August 2010

Published: 19 August 2010

\section{References}

1. Prüss A: Review of epidemiological studies on health effects from exposure to recreational water. I J Epidemio/ 1998, 27:1-9.

2. Kelsey $H$, Porter DE, Scott G, Neet M, White D: Using geographic information systems and regression analysis to evaluate relationships between land use and fecal coliform bacterial pollution. J Exp Mar Biol Ecol 2004, 298:197-209.

3. Muirhead RW, Collins RP, Bremer PJ: Numbers and transported state of Escherichia coli in runoff direct from fresh cowpats under simulated rainfall. Lett Appl Microbiol 2006, 42:83-87.

4. Saini $R$, Halverson $L J$, Lorimor JC: Rainfall timing and frequency influence on leaching of Escherichia coli RS2G through soil following manure application. J Environ Qual 2003, 32:1865-1872.

5. Kay D, Fleisher JM, Salmon RL, Jones F, Wyer MD, Godfree AF, ZelenauchJacquotte Z, Shore R: Predicting likelihood of gastroenteritis from sea bathing: results from randomised exposure. Lancet 1994, 344:905-909.

6. Van-Asperen IA, Medema G, Borgdorff MW, Sprenger MJW, Havelaar AH: Risk of gastroenteritis among triathletes in relation to faecal pollution of fresh waters. I J Epidemiol 1998, 27:309-315.

7. Wiedenmann A, Dietz K, Krüger P: Epidemiological determination of disease risks from bathing. Eberhard karls Universität Tübingen 2004, Final report.

8. Berg RD: The indigenous gastrointestinal microflora. Trends Microbiol 1996, 4:430-435.

9. Gordon DM, Cowling A: The distribution and genetic structure of Escherichia coli in Australian vertebrates: host and geographic effects. Microbiology 2003, 149:3575-3586.

10. Arana I, Orruno M, Perez-Pascual D, Seco C, Muela A, Barcina I: Inability of Escherichia coli to resuscitate from the viable but nonculturable state. FEMS Microbiol Ecol 2007, 62:1-11.

11. Habteselassie M, Bischoff M, Blume E, Applegate B, Reuhs B, Brouder S, Turco RF: Environmental controls on the fate of Escherichia coli in soil. Wat Air Soil Pollut 2008, 190:143-155.

12. Rozen $Y$, Belkin S: Survival of enteric bacteria in seawater. FEMS Microbiol Rev 2001, 25:513-529.

13. Artz RRE, Killham K: Survival of Escherichia coli $0157: H 7$ in private drinking water wells: influences of protozoan grazing and elevated copper concentrations. FEMS Microbiol Lett 2002, 216:117-122. 
14. Byappanahalli MN, Whitman RL, Shively DA, Sadowsky MJ, Ishii S: Population structure, persistence, and seasonality of autochthonous Escherichia coli in temperate, coastal forest soil from a Great Lakes watershed. Environ Microbiol 2006, 8:504-513.

15. Walk ST, Alm EW, Calhoun LM, Mladonicky JM, Whittam TS: Genetic diversity and population structure of Escherichia coli isolated from freshwater beaches. Environ Microbiol 2007, 9:2274-2288.

16. Winfield MD, Groisman EA: Role of nonhost environments in the lifestyles of Salmonella and Escherichia coli. Appl Environ Microbiol 2003, 69:3687-3694

17. Ishii S, Ksoll WB, Hicks RE, Sadowsky MJ: Presence and growth of naturalized Escherichia coli in temperate soils from Lake Superior watersheds. Appl Environ Microbiol 2006, 72:612-621.

18. Power ML, Littlefield-Wyer J, Gordon DM, Veal DA, Slade MB: Phenotypic and genotypic characterization of encapsulated Escherichia coli isolated from blooms in two Australian lakes. Environ Microbiol 2005, 7:631-640.

19. Farnleitner AH, Kreuzinger N, Kavka GG, Grillenberger S, Rath J, Mach RL: Simultaneous detection and differentiation of Escherichia coli populations from environmental freshwaters by means of sequence variations in a fragment of the $\beta$-D-glucuronidase gene. Appl Environ Microbiol 2000, 66:1340-1346

20. Ram JL, Ritchie RP, Fang J, Gonzales FS, Selegean JP: Sequence-based source tracking of Escherichia coli based on genetic diversity of $\beta$-D-glucuronidase. J Environ Qual 2004, 33:1024-1032.

21. Dombek PE, Johnson LAK, Zimmerley ST, Sadowsky MJ: Use of repetitive DNA sequences and the PCR to differentiate Escherichia coli isolates from human and animal sources. Appl Environ Microbiol 2000, 66:2572-2577.

22. Johnson LAK, Brown MB, Carruthers EA, Ferguson JA, Dombek PE, Sadowsky MJ: Sample size, library composition, and genotypic diversity among natural populations of Escherichia coli from different animals influence accuracy of determining sources of fecal pollution. App/ Environ Microbiol 2004, 70:4478-4485.

23. Carson CA, Shear BL, Ellersieck MR, Asfaw A: Identification of fecal Escherichia coli from humans and animals by ribotyping. Appl Environ Microbiol 2001, 67:1503-1507.

24. Harwood VJ, Whitlock J, Withington V: Classification of antibiotic resistance patterns of indicator bacteria by discriminant analysis: use in predicting the source of fecal contamination in subtropical waters. Appl Environ Microbiol 2000, 66:3698-3704.

25. Vantarakis A, Venieri D, Komninou G, Papapetropoulou M: Differentiation of faecal Escherichia coli from humans and animals by multiple antibiotic resistance analysis. Lett Appl Microbiol 2006, 42:71-77.

26. Gordon DM, Clermont O, Tolley H, Denamur E: Assigning Escherichia coli strains to phylogenetic groups: multi-locus sequence typing versus the PCR triplex method. Environ Microbiol 2008, 10:2484-2496.

27. Herzer PJ, Inouye S, Inouye M, Whittam TS: Phylogenetic distribution of branched RNA-linked multicopy single-stranded DNA among natural isolates of Escherichia coli. J Bacteriol 1990, 172:6175-6181.

28. Wirth T, Falush D, Lan R, Colles F, Mensa P, Wieler LH, Karch H, Reeves PR, Maiden MCJ, Ochman H, Achtman M: Sex and virulence in Escherichia coli: an evolutionary perspective. Mol Microbiol 2006, 60:1136-1151.

29. Tenaillon O, Skurnik D, Picard B, Denamur E: The population genetics of commensal Escherichia coli. Nature Rev Microbiol 2010, 8:207-217.

30. Picard B, Garcia JS, Gouriou S, Duriez P, Brahimi N, Bingen E, Elion J, Denamur E: The link between phylogeny and virulence in Escherichia coli extraintestinal infection. Infect Immun 1999, 67:546-553.

31. Duriez P, Clermont O, Bonacorsi S, Bingen E, Chaventre A, Elion J, Picard B, Denamur E: Commensal Escherichia coli isolates are phylogenetically distributed among geographically distinct human populations. Microbiology 2001, 147:1671-1676.

32. Escobar-Paramo P, Grenet K, Le Menac'h A, Rode L, Salgado E, Amorin C, Gouriou S, Picard B, Rahimy MC, Andremont A, Denamur E, Ruimy R: Largescale population structure of human commensal Escherichia coli isolates. Appl Environ Microbiol 2004, 70:5698-5700.

33. Skurnik D, Bonnet D, Bernede-Bauduin C, Michel R, Guette C, Becker JM, Balaire C, Chau F, Mohler J, Jarlier V, Boutin JP, Moreau B, Guillemot D, Denamur $E$, Andremont A, Ruimy R: Characteristics of human intestinal Escherichia coli with changing environments. Environ Microbiol 2008, 10:2132-2137.
34. Clermont O, Lescat M, O'Brien CL, Gordon DM, Tenaillon O, Denamur E: Evidence for a human-specific Escherichia coli clone. Environ Microbiol 2008, 10:1000-1006.

35. Escobar-Paramo P, Menac'h L, Le Gall T, Amorin C, Gouriou S, Picard B, Skurnik D, Denamur E: Identification of forces shaping the commensal Escherichia coli genetic structure by comparing animal and human isolates. Environ Microbiol 2006, 8:1975-1984.

36. Walk ST, Mladonicky JM, Middleton JA, Heidt AJ, Cunningham JR, Bartlett P, Sato K, Whittam TS: Influence of antibiotic selection on genetic composition of Escherichia coli populations from conventional and organic dairy farms. Appl Environ Microbiol 2007, 73:5982-5989.

37. Agence Française de Sécurité Sanitaire des Aliments (AFSSA): Usages vétérinaires des antibiotiques, résistance bactérienne et conséquences pour la santé humaine. Annual report 2006, France.

38. Dussart-Baptista L, Massei N, Dupont J-P, Jouenne T: Transfer of bacteria contaminated particles in a karst aquifer: evolution of contaminated materials from a sinkhole to a spring. J Hydrol 2003, 284:285-295.

39. Skurnik D, Ruimy R, Andremont A, Amorin C, Rouquet P, Picard B, Denamur $E$ : Effect of human vicinity on antimicrobial resistance and integrons in animal faecal Escherichia coli. J Antimicrob Chemother 2006, 57:1215-1219.

40. Walk ST, Alm EW, Gordon DM, Ram JL, Toranzos GA, Tiedje JM, Whittam TS: Cryptic lineages of the genus Escherichia. Appl Environ Microbiol 2009, 75:6534-6544.

41. Reischer $\mathrm{GH}$, Haider JM, Sommer R, Stadler H, Keiblinger KM, Hornek R, Zerobin W, Mach RL, Farnleitner AH: Quantitative microbial faecal source tracking with sampling guided by hydrological catchment dynamics. Environ Microbiol 2008, 10:2598-2608.

42. Clermont $\mathrm{O}$, Bonacorsi S, Bingen E: Rapid and simple determination of the Escherichia coli phylogenetic group. Appl Environ Microbiol 2000, 66:4555-4558.

43. Clermont O, Johnson JR, Menard M, Denamur E: Determination of Escherichia coli $\mathrm{O}$ types by allele-specific polymerase chain reaction: application to the $\mathrm{O}$ types involved in human septicemia. Diagn Microbiol Infect Dis 2007, 57:129-136.

44. Comité de l'Antibiogramme de la Société Française de Microbiologie: Communiqué du comité de l'antibiogramme de la société française de microbiologie. Bulletin de la Société Française de Microbiologie 2001, 2-13.

doi:10.1186/1471-2180-10-222

Cite this article as: Ratajczak et al:: Influence of hydrological conditions on the Escherichia coli population structure in the water of a creek on a rural watershed. BMC Microbiology 2010 10:222.

\section{Submit your next manuscript to BioMed Central and take full advantage of:}

- Convenient online submission

- Thorough peer review

- No space constraints or color figure charges

- Immediate publication on acceptance

- Inclusion in PubMed, CAS, Scopus and Google Scholar

- Research which is freely available for redistribution

Submit your manuscript at www.biomedcentral.com/submit
C Biomed Central 